\title{
PENGARUH PEMANASAN MICROWAVE TERHADAP MORFOLOGI DAN LUAS PERMUKAAN MATERIAL ZEOLITE NaX
}

\author{
${ }^{1}$ Hilman I. Umam, ${ }^{2} \cdot$ Tina Hernawati \\ ${ }^{1,2 .}$ Staff Pengajar Program Studi Teknik Industri, Fakultas Teknik \\ Universitas Muhammadiyah Tangerang \\ Jl. Perintis Kemerdekaan I/33, Cikokol, Kota Tangerang \\ Email : umam.hilman@gmail.com, tinahernawati@umt.ac.id
}

\begin{abstract}
A b s trak
Pengaruh lamanya waktu pemanasan microwave pada sintesis material zeolite NaX telah dipejari pada penelitian ini. Sintesis zeolite NaX dilakukan dengan menggunakan bantuan pemanasan microwave dengan variasi waktu selama 1 dan 5 menit. Berdasarkan hasil karakterisasi Scanning electron microscopy (SEM) menunjukan bahwa semakin lama waktu pemanasan microwave ukuran partikel menjadi semakin kecil dan aglomerasi yang terjadi pada sampel menjadi relatif berkurang. Disisi lain hasil karakterisasi Brunauer Emmet Teller (BET) menunjukan bertambahnya luas permukaan spesifik dari sampel zeolite NaX ketika dilakukan pemanasan dengan microwave yang lebih lama. Hal ini menunjukan bahwa pemanasan microwave mempengaruhi morfologi dan luas permukaan dari material zeolite NaX. Pemanasan dengan menggunakan energi microwave dapat mempercepat proses nukleasi pada sampel sehingga mengakibatkan proses pertumbuhan sampel menjadi lebih seragam. Dengan mengecilnya ukuran sebuah partikel dan luasnya permukaan suatu partikel, maka dapat meningkatkan keefektifitasan sampel zeolite NaX pada pengaplikasiannya sebagai katalis. Hal ini dapat terjadi karena semakin luasnya permukaan katalis akan mempercepat terjadinya reaksi karena mampu menurunkan energi aktivasi dari suatu reaksi kimia.
\end{abstract}

Kata Kunci : Pemanasan microwave, zeolite NaX.

\section{PENDAHULUAN}

Zeolite merupakan mineral kristalin aluminosilikat yang memiliki pori berskala molekuler dengan rentang $0.3-1.5$ nanometer. Zeolite tersusun dari kerangka dasar $\mathrm{SiO}_{4}{ }^{-4}$ dan $\mathrm{AlO}_{4}^{-5}$ yang relatif teratur dan saling terhubung melalui atom oksigen di empat sudutnya sehinga akan membentuk struktur cincin yang selanjutnya dapat membentuk pori. Dengan strukutur tersebut, zeolite sudah mulai banyak digunakan dalam dunia perminyakan sejak tahun 1960-an sebagai katalis dalam proses oil cracking yaitu pemutusan rantai hidrokarbon panjang menjadi rantai hidrokarbon yang lebih sederhana [1]. Penggunaan zeolite sebagai katalis sangat efektif karena mempunyai struktur berongga atau berpori sehingga menyebabkan bagian permukaannya menjadi sangat luas. Semakin luasnya permukaan dari katalis yang berinteraksi dengan reaktan, maka akan menyebabkan semakin cepat suatu reaksi kimia terjadi. Zeolite dapat terbentuk dengan baik secara alami maupun sintesis dan diketahui bahwa beberapa daerah di Indonesia memiliki material zeolite alam dengan jenis yang berbeda seperti zeolite dari daerah Bogor dengan tipe zeolite heulandite, zeolite dari daerah Bayah dengan tipe zeolite mordenite dan clipnotilolite, serta zeolite dari daerah Lampung dengan tipe mordenite, cristobalite, dan albite [2].

Zeolite alam masih mempunyai beberapa kelemahan jika digunakan sebagai katalis karena memiliki kandungan mineral pengotor yang cukup tinggi sehingga dapat mengganggu struktur permukaan zeolite dan akibatnya berdampak pada kurang baiknya sifat katalitik dari zeolite tersebut. Selain itu ukuran dari zeolite alam masih relatif besar dalam orde mikrometer sehingga memiliki luas permukaan yang lebih kecil jika dibandingkan dengan material yang berukuran nanometer. Sehingga untuk membuat zeolite alam bisa dijadikan sebagai katalis yang baik perlu dilakukan proses aktivasi dengan pamanasan pada temperature $300^{\circ} \mathrm{C}$ untuk menghilangkan material-material pengotor yang menghalangi rongga-rongga dari zeolite dan juga 
perlu dilakukan proses milling selama 8 jam untuk mereduksi ukuran dari partikel zeolite tersebut [2]. Dengan proses aktivasi melalui dua tahap tersebut sehingga membuat biaya produksi dari zeolite meningkat, maka zeolite alam masih belum memiliki efektifitas yang tinggi jika digunakan sebagai katalis dalam proses oil cracking. Berbeda dengan zeolite alam, zeolite sintetik memiliki kandungan yang lebih murni dan tidak banyak memiliki material pengotor karena proses sintesisnya bisa terkontrol. Selain itu, zeolite sintetik juga memiliki keunggulan lain dibandingkan dengan zeolite alam yaitu kristalinitas yang lebih tinggi [3]. Salah satu jenis zeolite yang umum digunakan sebagai katalis adalah zeolite dengan tipe Faujasite. Jenis zeolite faujasite memiliki ukuran rongga yang relatif besar sehingga membuat zeolite tipe faujasite memiliki luas permukaan yang besar.

Alumina dan silikat menjadi sumber utama dalam sintesis zeolite faujasite. Berdasarkan rasio kandungan silika dan alumina pada kerangkanya, zeolite faujasite dibagi menjadi zeolite $\mathrm{X}$ dan zeolite Y. Pada zeolite X perbandingan silika dan aluminanya sekitar 2 dan 3, sedangkan pada zeolite Y nilai perbandingannya sekitar 3 keatas. Dari dua jenis zeolite faujasite tersebut zeolite $\mathrm{X}$ atau sering dikenal juga dengan $\mathrm{NaX}$ merupakan zeolite yang bisa disintesis pada temperatur yang relatif rendah sehingga tidak membutuhkan energi yang cukup besar. Proses sintesis dari zeolite sintetik bisa berlangsung dalam waktu yang cukup lama. Zhang, et. al. melaporkan bahwa struktur kristal dari zeolite $\mathrm{NaX}$ terbentuk dengan baik setelah proses kristalisasi selama 28 sampai 40 hari [4]. Cukup lamanya proses sintesis dari zeolite sintetik tersebut sehingga perlu diterapkan cara untuk membuat proses sintesis dari zeolite menjadi lebih cepat dan mudah. Salah satu metode atau cara yang bisa digunakan adalah metode sintesis dengan bantuan pemanasan microwave.

Penggunaan energi dari radiasi microwave pada proses sintesis dan reaksi kimia saat ini sudah banyak dipelajari dan diaplikasikan. Pemanasan microwave diketahui lebih efisien untuk berbagai proses pemanasan sehingga membuat proses sintesis menjadi lebih hemat energi dibandingkan dengan proses pemanasan secara konvensional [5]. Tidak hanya mengurangi konsumsi energi, pemanasan dengan menggunakan energi microwave juga bisa mengurangi lamanya proses sintesis dan menghasilkan material dengan struktur yang lebih seragam. Hasil tersebut diperoleh karena pemanasan dengan menggunkaan energi microwave membuat proses nukleasi lebih cepat sehingga membuat proses pertumbuhan menjadi lebih seragam [5]. Oleh karena itu dalam penelitian ini akan dilakukan sinesis zeolite $\mathrm{NaX}$ dengan bantuan microwave yang diharapkan mampu membuat proses sintesis bisa berlangsung dengan waktu yang relatif singkat dan proses yang mudah.

\section{METODE PENELITIAN}

Dalam proses sintesis zeolite $\mathrm{NaX}$ digunakan $\mathrm{Na}_{2} \mathrm{SiO}_{3}$ (Merck Chemical) sebagai sumber silikat dan $\mathrm{NaAl}_{2} \mathrm{O}_{3}$ (Merck Chemical) sebagai sumber aluminat. $\mathrm{Na}_{2} \mathrm{SiO}_{3}$ kemudian dilarutkan kedalam air distilasi untuk menghasilkan larutan silikat, sedangkan $\mathrm{NaAl}_{2} \mathrm{O}_{3}$ dicampurkan kedalam larutan $\mathrm{NaOH}$ yang sudah dibuat sebelumnya untuk menghasilkan larutan aluminat. Setelah itu larutan silikat dititrasi kedalam larutan aluminat lalu diaduk dengan menggunakan magnetic stirrer dengan kecepatan 800 RPM selama 30 menit sampai larutan bercampur seluruhnya. Larutan hasil pencampuran tersebut kemudian dipanaskan dengan menggunakan bantuan microwave dengan variasi waktu yaitu 1 dan 5 menit untuk melihat pengaruh waktu lamanya pemanasan microwave terhadap zeolite $\mathrm{NaX}$ yang dihasilkan. Setelah dilakukan pemanasan dengan microwave, sampel kemudian disimpan pada temperatur ruang selama beberapa waktu untuk proses kristalisasi. Setelah itu, dilakukan proses filtrasi dan pencucian dengan air distilasi untuk menghilangkan material-material pengotor yang masih terdapat pada sampel. Endapan hasil filtrasi kemudian dikeringkan dengan menggunakan oven pada temperatur $100^{\circ} \mathrm{C}$ selama 24 jam hingga diperoleh serbuk halus berwarna putih. Sampel yang sudah dalam bentuk serbuk dikarakterisasi untuk mengetahui sejauh mana keberhasilan dalam proses sintesis yang sudah dilakukan. Untuk melihat morfologi dan distribusi rata-rata ukuran partikelnya digunakan SEM (scanning electron microscopy, JEOL-JSM-6510LA) dan untuk melihat luas permukaan dari sampel zeolite NaX digunakan BET (Brunneur-Emmet-Teller, Quantachrome Autosorb Instrument). 


\section{HASIL DAN PEMBAHASAN}

Hasil karakterisasi SEM yang ditunjukan pada gambar 1 memperlihatkan morfologi dari zeolite NaX. Berdasarkan hasil SEM tersebut terlihat bahwa pada sampel zeolite NaX dengan pemanasan microwave yang lebih lama relatif menunjukan terjadinya pengurangan aglomerasi. Pada sampel zeolite $\mathrm{NaX}$ dengan pemanasan microwave selama 1 menit masih terlihat gumpalangumpalan dan realtif tidak jelas terlihat bentuk moerfologi dari partikelnya. Sedangkan untuk sampel zeolite dengan waktu pemanasan microwave selama 5 menit sudah terlihat bentuk morfologi dari partikelnya walaupun masih tampak terlihat adanya aglomerasi. Pengurangan terjadinya aglomerasi pada sampel zeolite $\mathrm{NaX}$ dengan pemanasan microwave menunjukan adanya pengaruh waktu pemanasan tersebut terhadap morfologi dari sampel zeolite yang dihasilkan. Hal itu disebabkan karena pemanasan dengan menggunakan bantuan microwave membuat proses nukleasi yang semakin cepat sehingga membuat proses pertumbuhan partikel menjadi semakin seragam [5].

Berdasarkan dari hasil SEM tersebut, kemudian dilakukan juga pengukuran distribusi ukuran partikel dan diperoleh ukuran rata-rata partikel untuk sampel zeolite NaX dengan pemanasan microwave selama 1 menit dan dengan pemanasan microwave selama 5 menit berturutturut adalah 350,5 nm, dan 243,9 nm. Berdasarkan hasil tersebut menunjukan bahwa pemanasan dengan bantuan microwave membuat ukuran partikel dari zeolite NaX menjadi semakin kecil. Hal itu berkaitan dengan pemanasan microwave yang mampu mereduksi terjadinya aglomerasi dari partikel zeolite NaX sehingga ukuran partikelnya menjadi semakin kecil.
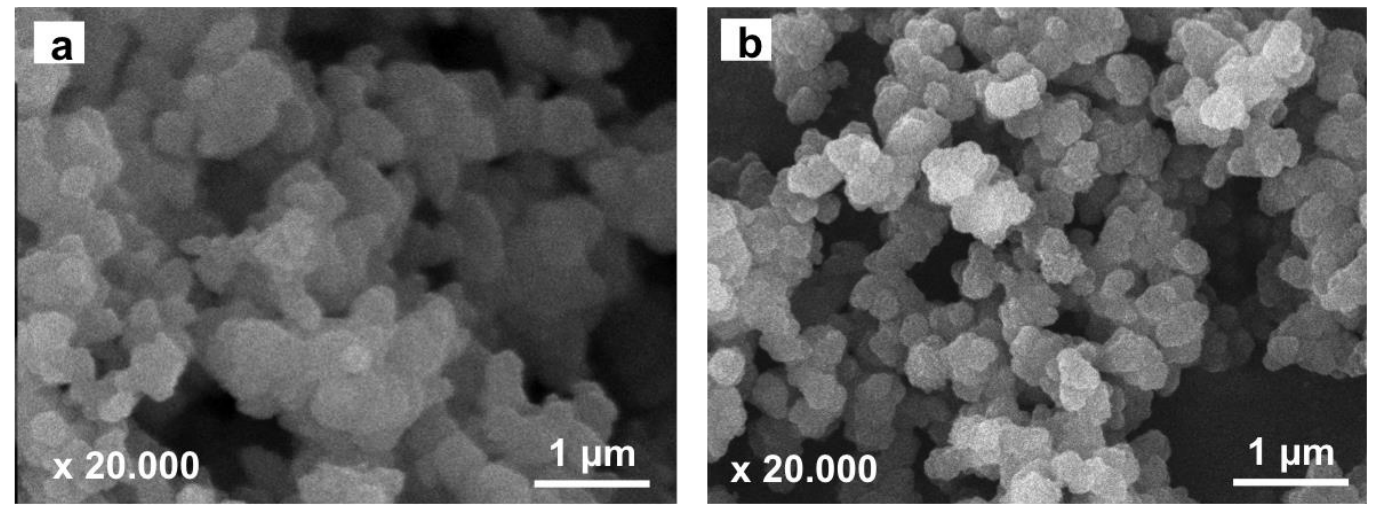

Gambar 1. Hasil SEM dari zeolite NaX dengan pemanasan microwave,

(a) 1 menit, dan (b) 5 menit

Hasil karaterisasi SEM yang menunjukan pengaruh pemanasan microwave terhadap perubahan morfologi dan ukuran partikel dari sampel zeolite sehingga menghasilkan perubahan luas permukaan dari partikel zeolite yang ditunjukan oleh hasil BET. Tabel 1. menyajikan hasil karakterisasi BET yang menunjukan bahwa semakin lama permanasan microwave, luas permukaan spesifik dari sampel zeolite $\mathrm{NaX}$ menjadi semakin besar.

Tabel 1. Luas permukaan sampel zeolite NaX dengan variasi waktu pemanasan microwave

\begin{tabular}{|c|c|c|}
\hline Sampel & Waktu pemanasan microwave & Luas permukaan \\
\hline \multirow{2}{*}{ Zeolite NaX } & 1 menit & $55.99 \mathrm{~m}^{2} / \mathrm{g}$ \\
\cline { 2 - 3 } & 5 menit & $204.013 \mathrm{~m}^{2} / \mathrm{g}$ \\
\hline
\end{tabular}

Perubahan morfologi dan ukuran partikel dari sampel zeolite NaX yang disintesis dengan variasi waktu pemanasan microwave menghasilkan perubahan terhadap luas permukaan total dari sampel zeolite $\mathrm{NaX}$ tersebut. Semakin lama pemanasan microwave yang diberikan pada sampel membuat luas permukaan total dari sampel menjadi semakin besar. Hasil tersebut berhubungan dengan ukuran partikel dari zeolite $\mathrm{NaX}$ yang semakin kecil serta pemanasan microwave yang kemungkinan membuat struktur pori yang dimiliki oleh zeolite $\mathrm{NaX}$ menjadi semakin terbentuk. Luas permukaan total dari sebuah material akan sangat berkaitan dengan ukuran partikel dan struktur pori yang dimiliki oleh material tersebut. Sehingga hasil BET ini mendukung terhadap hasil karakterisasi SEM yang menunjukan ukuran partakel zeolite yang semakin kecil akibat lamanya waktu pemanasan dengan menggunakan microwave. 


\section{KESIMPULAN}

Telah berhasil dilakukan sintesis material zeolite $\mathrm{NaX}$ dengan variasi waktu pemanasan microwave selama 1 dan 5 menit. Berdasarkan hasil karakterisasi SEM menunjukan bahwa terjadinya pengurangan aglomerasi pada sampel zeolite $\mathrm{NaX}$ dengan pemanasan microwave yang semakin lama. Dengan berkurangnya aglomerasi pada sample zeolite NaX menghasilkan ukuran partikel rata-rata dari sampel menjadi semakin kecil dengan pemanasan micrwaove yang lebih lama. Untuk waktu pemanasan microwave selama 1 dan 5 menit didapatkan ukuran partikel ratarata berturut-turut sebesar 350,5 nm, dan 243,9 nm. Kemudian berdasarkan karakterisasi BET menunjukan bahwa semakin lama permanasan microwave, luas permukaan spesifik dari sampel zeolite NaX menjadi semakin besar.

\section{DAFTAR PUSTAKA}

Degnan, T. F., Chitnis, G. K., \& Schipper, P. H. (2000). History of ZSM-5 fluid catalytic cracking additive development at Mobil. Microporous and Mesoporous materials, 35, 245-252.

Merissa, S., Fitriani, P., Iskandar, F., Abdullah, M., Khairurrijal. (2013). Preliminary Study of Natural Zeolite as Catalyst for Decreasing the Viscosity of Heavy Oil. AIP Conf. Proc. 1554, 131.

Mukti, R. R., Wustoni, S., Wahyudi, A., \& Ismunandar, I. (2013). Converison of the Low Quality Indonesian Naturally-Occurring Minerals into Selective Type of Zeolites by Seed-Assisted Synthesis Method. Indonesian Journal of Chemistry, 13(3), 278-282.

Zhang, X., Tong, D., Zhao, J., \& Li, X. (2013). Synthesis of NaX zeolite at room temperature and its characterization. Material Letters, 104, 80-83.

Xiangju Meng \& Feng-Shou Xiao. (2014). Green Routes for Synthesis of Zeolites. Chem. Rev. $114,1521-1543$. 